\title{
Characterization of TectoRNA Assembly with Cationic Conjugated Polymers
}

\author{
Bin Liu, Stéphanie Baudrey, Luc Jaeger*, Guillermo C. Bazan* \\ Departments of Chemistry and Biochemistry and Materials, Institute for Polymers and \\ Organic Solids, University of California, Santa Barbara, CA 93106
}

\section{Supplementary Information}

\section{Materials \& Methods \\ General Details.}

The UV-Vis absorption spectra were recorded on a Shimadzu UV-2401 PC diode array spectrometer. Photoluminescence spectra were obtained on a Spex Fluorolog 2 spectrometer, using 90 degree angle detection for solution samples. ODs of all the RNAs were determined using a Thermo Spectronic Biomate 3. The water-soluble conjugated polymer $(\mathbf{P})$ was prepared as previously reported. ${ }^{\mathrm{i}}$

\section{DNA Template and RNA Synthesis}

RNA molecules were prepared in vitro by run-off transcription of DNA templates using T7 RNA polymerase. DNA templates for in vitro transcription were generated by amplifying a synthetic DNA molecule (RNAn.mat; n: 1 to 4), coding for the antisense sequence of the desired RNA molecule, with a forward primer (RNAn.fwd) containing 
the T7 RNA polymerase promoter, and a reverse primer (RNAn.Rev). RNA1 DNA template was PCR generated by amplifying RNA1.mat (AAGGAGCGTGGGGTAGAACCAAGTTTCCCCGGAACTACCCTTCTCCC) with RNA1.rev (AAGGAGCGTGGGGTAGA) and RNA1.fwd (TTCTAATACGA CTCACTATAGGGAGAAGGGTAG TTC). RNA2 DNA template was PCR generated by amplifying RNA2.mat (AAGGACTTAGGAAGAACCAAGTTCCCCCGGAAC TTCCATATCCCTATAGTGAGTCGTATTAGAA) with RNA2.rev (AAGGACTT AGGAAGAACC) and RNA2.fwd (TTCTAATACGACTCACTATAGGGATA TGGAAGTTCC). RNA3 DNA template was PCR generated by amplifying RNA3.mat (AAGGACTTAGGAAGAACCAAGTTACCCCGGAACTTCCATATCCCTATAGTGA GTCGTATTAGAA) with RNA2.rev and RNA2.fwd. RNA4 DNA template was PCR generated by amplifying RNA4.mat (AAGGACTTAGGAAGAACCAAGCGAACC CGGAACTTCCATATCCCTATAGTGAGTCGTATTAGAA) with RNA2.rev and RNA2.fwd.

The forward and reverse primers were designed to hybridize to the template sequence (RNAn.mat) with $T_{m} \sim 54{ }^{\circ} \mathrm{C}$. Typical PCR reactions were carried out in a total volume of $200 \mu \mathrm{L}$ and contained $2 \mathrm{mM} \mathrm{MgCl}, 50 \mathrm{mM} \mathrm{KCl}, 10 \mathrm{mM}$ Tris $\mathrm{pH} 8.9,0.5 \%$ NP-40, $1 \mathrm{mg} / \mathrm{mL}$ gelatin, $0.5 \mathrm{mM}$ of each dNTP, $2 \mathrm{nM}$ of RNAn.mat, and $1 \mu \mathrm{M}$ RNAn.fwd and RNAn.rev. The reactions were calibrated to produce 150 pmol of DNA template after 20 cycles $\left(94{ }^{\circ} \mathrm{C}\right.$ for $1 \min 15 \mathrm{~s} ; 53{ }^{\circ} \mathrm{C}$ for $1 \min 15 \mathrm{~s} ; 72{ }^{\circ} \mathrm{C}$ for $1 \min 15$ 
s). After purification of the PCR products using the QiaQuick PCR purification kit, 90 pmol of each DNA template was incubated for $4 \mathrm{~h}$ at $37^{\circ} \mathrm{C}$ with T7 RNA polymerase (4 $\mathrm{U} / \mu \mathrm{L}$ ) in a buffer containing $10 \mathrm{mM} \mathrm{MgCl}, 2 \mathrm{mM}$ spermidine, $50 \mathrm{mM}$ Tris $\mathrm{pH}$ 7.5, 2.5 $\mathrm{mM}$ of each NTP, $1 \mathrm{mM}$ DTT, $0.01 \mathrm{U} / \mu \mathrm{L}$ inorganic pyrophosphatase and $0.8 \mathrm{U} / \mu \mathrm{L}$ RNasin. After the reaction, the DNA templates were degraded by incubating with FPLC pure RQ1 DNase $(0.4 \mathrm{U} / \mu \mathrm{L})$ for $30 \mathrm{~min}$ at $37^{\circ} \mathrm{C}$. The RNA products were purified using denaturing polyacrylamide gel electrophoresis (10\% acrylamide, $8 \mathrm{M}$ urea). After elution overnight at $4^{\circ} \mathrm{C}$ in $(200 \mathrm{mM} \mathrm{NaCl}, 10 \mathrm{mM}$ Tris $\mathrm{pH} 7.5,0.5 \mathrm{mM}$ EDTA), the RNA was ethanol precipitated, rinsed twice with $90 \%$ ethanol, dried and dissolved in water. GMP RNA (5') was synthesized in a similar way: 90 pmol of each DNA template was incubated for $4 \mathrm{~h}$ at $37^{\circ} \mathrm{C}$ with T7 RNA polymerase $(4 \mathrm{U} / \mu \mathrm{L})$ in a buffer containing 10 $\mathrm{mM} \mathrm{MgCl}_{2}, 2 \mathrm{mM}$ spermidine, $50 \mathrm{mM}$ Tris $\mathrm{pH} 7.5,2.5 \mathrm{mM}$ of each A/U/CTP, $1 \mathrm{mM}$ DTT, $0.01 \mu \mathrm{g} / \mu \mathrm{L}$ inorganic pyrophosphatase, $5 \mathrm{mM} \mathrm{Li}_{2}-\mathrm{GMP}(\mathrm{S}), 0.2 \mathrm{mM}$ GTP, and 0.8 $\mathrm{U} / \mu \mathrm{L}$ RNasin, with $2.5 \mu \mathrm{L}$ of GTP $(10 \mathrm{mM})$ added to the mixture in every $25 \mathrm{~min}$. Labeling of 500 pmol of GMP RNA was done during $1 \mathrm{~h}$ at $30{ }^{\circ} \mathrm{C}$ in dark with $8 \mathrm{mM}$ of 5-iodoacetamidofluorescein in a buffer containing $50 \mu \mathrm{M}$ DTT, $2 \mathrm{mM} \mathrm{Na}$ EDTA (pH 8), $50 \mathrm{mM}$ Tris (pH 8.3). RNA labeling was quenched by adding $1 \mu \mathrm{L}$ of DTT $(100 \mathrm{mM})$ and the labeled RNA was purified in $10 \%$ acrylamide bisacrylamide (19:10)/8 M urea and washed in a similar way as for the RNA and RNA-GMP(S). 


\section{Non-Denaturing Gel Electrophoresis Characterization}

RNA at various concentrations were heated at $90{ }^{\circ} \mathrm{C}$ for $1 \mathrm{~min}$, immediately cooled on ice, and allowed to dimerize for $30 \mathrm{~min}$ at $30{ }^{\circ} \mathrm{C}$ in $89 \mathrm{mM}$ Tris borate buffer $(\mathrm{pH}=8.3), 15 \mathrm{mM}$ of $\mathrm{Mg}(\mathrm{OAc})_{2}$ and $5 \%$ glycol. Monomers and dimers were then separated by electrophoresis at $15^{\circ} \mathrm{C}$ on $9 \%$ (30:1) non-denaturing polyacrylamide gels. PAGE electrophoresis experiments were performed in a cold room at $4{ }^{\circ} \mathrm{C}$ for better temperature control and to avoid gel overheating. The $K_{d}$ corresponds to the RNA concentration at which half of the RNA is dimerized.

\section{RNA Concentration Measurements and RNA Sample Preparation}

ODs of all the RNAs were determined by the $260 \mathrm{~nm}$ absorbance measurements done on a $1 / 70$ diluted sample in a $70 \mu \mathrm{L}$ quartz cuvette. Once the concentration of all the RNAs was established, a 1:1.2 mixture of RNA-F* and the target RNA strand was mixed for supra-molecular assembly. The mixtures were first heated at $90{ }^{\circ} \mathrm{C}$ for $1 \mathrm{~min}$, immediately cooled on ice for $3 \mathrm{~min}$, and then incubated at $30{ }^{\circ} \mathrm{C}$ for $2 \mathrm{~min}$. RNAs were assembled at $30{ }^{\circ} \mathrm{C}$ for $30 \mathrm{~min}$ in buffer ( $25 \mathrm{mM}$ HEPES $\left.(\mathrm{pH}=7.5), 15 \mathrm{mM} \mathrm{Mg}(\mathrm{OAc})_{2}\right)$, and then cooled on ice.

\section{Fluorescence Measurements}

Fluorescence intensities were determined from the integrated areas under emission spectra of both the donor $(\mathbf{P})$ and the acceptor fluorescein. The differences in 
energy transfer were compared by measuring the fluorescence intensity of the acceptor in the presence of the same concentration of the donor.

Fluorescent spectra were collected in buffer $\left(15 \mathrm{mM} \mathrm{Mg}(\mathrm{OAc})_{2}+25 \mathrm{mM}\right.$ HEPEs $\mathrm{pH}$ 7.5) using a $150 \mu \mathrm{L}$ cuvette. Measurements, performed at temperatures between 15 and $18^{\circ} \mathrm{C}$ in a room with air conditioning, were taken $30 \mathrm{~s}$ after polymer addition to the RNA solution equilibrated at $15^{\circ}$. CCP solutions were added to annealed RNA mixtures at once. For the mixture of $100 \mu \mathrm{L}$ RNA1-F* and $\mathrm{RNA}_{\mathrm{T}}$ at $\left[\mathrm{RNA1}-\mathrm{F}^{*}\right]=5 \mathrm{nM}, 3 \mu \mathrm{L}$ of $\left[\mathbf{P}=5 \times 10^{-6} \mathrm{M}\right]$ solution were added. Similarly, $4 \mu \mathrm{L}$ of $[\mathbf{P}]=1 \times 10^{-4} \mathrm{M}$ solution were added to $100 \mu \mathrm{L}$ RNA-F* and $\mathrm{RNA}_{\mathrm{T}}$ at $\left[\mathrm{RNA1}-\mathrm{F}^{*}\right]=100 \mathrm{nM}$, and $30 \mu \mathrm{L}$ of $[\mathbf{P}]=1 \times 10^{-4}$ M solution were added to $100 \mu \mathrm{L}$ RNA1-F* and $\mathrm{RNA}_{\mathrm{T}}$ at $\left[\mathrm{RNA1}-\mathrm{F}^{*}\right]=1000 \mathrm{nM}$. The excitation wavelength was $380 \mathrm{~nm}$, which selectively creates $\mathbf{P}$ excited states. The emission intensity is normalized relative to polymer emission.

For experiments using FRET to estimate solution $\mathrm{K}_{d}$ values, different

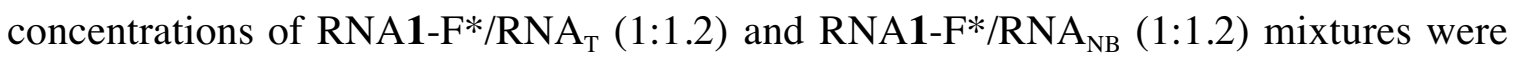
prepared. $4 \mu \mathrm{L}$ of $[\mathbf{P}]=1 \times 10^{-4} \mathrm{M}$ solution were added to $100 \mu \mathrm{L}$ of different concentrations ( $3 \mathrm{nM}, 5 \mathrm{nM}, 6 \mathrm{nM}, 10 \mathrm{nM}, 30 \mathrm{nM}, 60 \mathrm{nM}, 100 \mathrm{nM}$ ) of RNA1-F*/RNA (1:1.2) respectively for $\mathrm{K}_{d}$ measurement) of RNA1-F*/RNA $(1: 1.2)$ and RNA1$\mathrm{F}^{*} / \mathrm{RNA}_{\mathrm{NB}}$ (1:1.2). The emission spectra for both RNA pairs at each concentration were measured and the difference in dye emission intensities was calculated (after subtraction 
of residual polymer emission). A plot of $\left(\mathrm{I}_{\mathrm{T}}-\mathrm{I}_{\mathrm{NB}}\right) / \mathrm{I}_{\mathrm{NB}}$ against [RNA], shows the concentration range wherein the increased fluorescence is the result of dimerization. The $\mathrm{K}_{d}$ was thus calculated to be $6 \pm 2 \mathrm{nM}$.

${ }^{\mathrm{i}}$ Liu, B.; Wang, S.; Bazan G. C.; Mikhailovsky, A. J. Am. Chem. Soc. 2003, 125, 13306. 